Bangladesh J. Bot. 49(1): 71-74, 2020 (March)

\title{
MANAGEMENT OF FUSARIUM WILT OF TOMATO BY BOTANICALS AND BIOCONTROL AGENTS AND THEIR EFFECT ON YIELD
}

\author{
Mst J Khatun, KM Khalequzzaman ${ }^{1}$, Mst S Naher ${ }^{1}$ and FA Neela* \\ Department of Botany, University of Rajshahi, Rajshahi-6205, Bangladesh
}

Keywords: Management, Fusarium wilt, Botanicals, Biocontrol agents, Tomato

\begin{abstract}
Investigation was undertaken to screen out the extract of botanicals viz., neem leaf, neem oil, garlic, marsh paper plant, allamanda leaf, wood apple leaf, betel leaf and biological antagonists viz., Trichoderma viride and T. harzianum. Positive control was soil amendment with Provax and negative control with untreated soil. Soil drenching with Provax and untreated soil showed 7.65 and $37.5 \%$ wilt of tomato. Wilt incidence varied from $8.5-30.81 \%$. Botanicals and biocontrol agents had significant effect on yield of tomato. Provax gave the highest (30.55 t/ha) yield which was statistically identical to garlic extract (29.66 t/ha) and untreated control showed the lowest (20.19 t/ha) yield which was followed by soil drenching with neem leaf extract. Both the biocontrol agents viz., T. harzianum and T. viride as broth and compost significantly reduced wilt incidence of tomato in the field over control.
\end{abstract}

\section{Introduction}

Fusarium oxysporum f. sp. lycopersici is a highly destructive pathogen both in greenhouse and field conditions (Jaiswal et al. 2015). World-wide wilt is considered as one of the most economically important disease (Cal et al. 2004). Use of fungicides leads to severe environmental pollutions and reduction of beneficial microbes (Jaiswal et al. 2015). Non-chemical and ecofriendly botanicals and biocontrol agents as broad spectrum fungicides have been found to provide an answer to the non-discriminatory broad spectrum fungicides.

The antifungal and antimicrobial properties of several plant extracts and essential oils are investigated by many workers (Boulenouar et al. 2009, Pizana et al. 2010). It is generally assumed that the active constituents responsible for antifungal properties of the extracts are phytochemicals (Okwu 2004). Reduction in the population of Fusarium oxysporum with plant parts extract were reported by many workers (Bowers and Locke 2000, Pattanaik et al. 2002, Khayungarnnawee et al. 2004, Agbenin and Marley 2006). The antifungal activity of ethanol and acetone extract of leaves of nine medicinal plants against the causal agent of Fusarium wilt in tomato was assessed by Neela et al. (2014).

The antagonistic fungi Trichoderma spp. have been widely used against Fusarium spp. (ElRafai et al. 2003, Ahmed 2011, Hend and Perveen 2012). However, it is also reported that all of the isolates of Trichoderma spp. are not equally effective to control the pathogen in vitro and in vivo (Ramezani 2008). Therefore, the present investigation was to evaluate the management of Fusarium wilt of tomato by botanicals and biocontrol agents and to assess their effect on the yield of tomato in vivo condition.

\section{Materials and Methods}

The field experiment was conducted at Regional Agricultural Research Station, Ishurdi, Pabna, Bangladesh during 2011 - 2012. The experimental land was well ploughed and properly

*Author for correspondence: <nfarzanaashrafi@yahoo.com>. ${ }^{1}$ Spices Research Centre, BARI, Shibganj, Bogura, Bangladesh. 
leveled before bed preparation. Weeds and stubbles were removed from the field. Cow-dung @ 10 t/ha, urea @550 kg/ha, TSP @ 450 kg/ha and MP @ $250 \mathrm{~kg} / \mathrm{ha}$ were applied. BARI Tomato 14 was used in this experiment. The experiment was carried out following RCBD with three replications. Size of the plots was $3 \times 2 \mathrm{~m}$ and plant spacing was $60 \times 40 \mathrm{~cm}$. Fusariam oxysporum f. sp. lycopersici inoculum was mixed with soil before 2 weeks of plantation of tomato for establishment of fungi. Preparation of plant extracts was made according to Neela et al. (2014). One $\mathrm{ml}$ of prepared extract was mixed with $5 \mathrm{ml}$ of water which gave $1: 5$. Thirteen treatments of soil amendment with extract $(1: 5)$ is presented in Table 1. The inoculum of Fusarium oxysporum was applied only up to a depth of $6 \mathrm{~cm}$ in the soils i.e. $5 \mathrm{~g}$ of oat culture was mixed with soil of pit before two weeks of tomato plantation. The treatments were applied in pits during crop plantation. Intercultural operations were done as and when needed and to maintain the normal hygienic condition of crop in the field. Wilt incidence, number of fruit branches/plant, number of fruits/plant, weight of fruits/plant and yield ( $\mathrm{t} / \mathrm{ha}$ ) were recorded. The percentage of wilt of tomato was recorded by adopting the formula of Siddaramaiah et al. (1978).

Data were analyzed statistically to find out the level of significance and the variations among the respective data were compared following DMRT according to Gomez and Gomez (1984).

\section{Results and Discussion}

Effect of botanicals and biocontrol agents on yield contributing characters, yield and per cent wilt of tomato are presented in Table 1 . Wilt incidence of tomato was significantly influenced by the botanicals and biocontrol agents (Table 1). Wilt incidence varied from $7.65-37.50 \%$, where the lowest incidence was observed in soil amendment with Provax which was statistically similar to soil drenching with garlic extract and allamanda leaf extract. The highest incidence was observed in untreated soil which was not statistically similar to all other treatments. The highest number (12.00) of fruit branches per plant was recorded in soil drenching with Provax $(2 \mathrm{~g} / \mathrm{l}$ water) which was not statistically similar to all other treatments, and the lowest (7.56) number of fruit branches per plant was recorded in control which was statistically similar to soil drenching with Trichoderma harzianum broth. Soil drenching with Provax resulted the highest (19.26) number of fruits per plant which was followed by soil drenching with garlic extract, marsh pepper plant extract and allamanda leaf extract. Control resulted the lowest (11.90) number of fruits per plant which was also followed by soil drenching with neem leaf extract and betel leaf extract. The maximum weight $(365.94 \mathrm{~g})$ of fruits per plant was obtained from soil drenching with Provax which was statistically similar to garlic extract $(350.92 \mathrm{~g})$, and the lowest weight $(226.10 \mathrm{~g})$ of fruits per plant was obtained from control treatment which was statistically similar to soil drenching with neem leaf extract. Botanicals and biocontrol agents had significant effect on yield of tomato. Provax showed the highest yield (30.55 t/ha) which was statistically identical to garlic extract $(29.66 \mathrm{t} / \mathrm{ha})$ and control gave the lowest $(20.19 \mathrm{t} / \mathrm{ha})$ yield which was followed by soil drenching with neem leaf extract (Table 1).

Hassanein et al. (2010) conducted an experiment on the effect of neem (Azadiracta indica) leaf extract against Alternaria solani and Fusarium oxysporum, the causal agents of early blight and wilt of tomato plants, respectively. There was significant gradual increase in growth parameters when the plants were sprayed and irrigated with aqueous neem extract. In this study, neem leaf extract also showed satisfactory result against Fusarium oxysporum. Islam and Faruq (2012) studied the effects of some plant extracts against damping-off disease of some winter vegetable in the net house. The most effective treatment was with the neem leaf extract followed by garlic, clove and allamanda leaf extracts in terms of suppressing damping-off disease incidence with increasing plant growth characters. In the present study garlic extract gave the highest yield 
(29.66 t/ha) which was statistically identical to positive control (30.55 t/ha) followed by allamanda leaf extract. Other treatments also showed better performance in increasing yield and suppressing fusarium wilt disease of tomato. This result indicated that plant extract can be an excellent alternative of chemicals for wilt treatment. Present findings were correlated with Islam et al. (2006).

Table 1. Effect of botanicals and biocontrol agents on yield contributing characters, yield and percent wilt of tomato.

\begin{tabular}{|c|c|c|c|c|c|c|}
\hline \multicolumn{2}{|c|}{$\begin{array}{l}\text { Treatments with } \\
\text { concentration }\end{array}$} & $\begin{array}{l}\text { Wilted } \\
\text { plant } \\
(\%)\end{array}$ & $\begin{array}{l}\text { No. of fruits } \\
\text { branches/ } \\
\text { plant }\end{array}$ & $\begin{array}{l}\text { No. of } \\
\text { fruits/ } \\
\text { plant }\end{array}$ & $\begin{array}{l}\text { Wt. of } \\
\text { fruits/ plant } \\
\text { (g) }\end{array}$ & $\begin{array}{l}\text { Yield } \\
(\mathrm{t} / \mathrm{ha})\end{array}$ \\
\hline \multicolumn{2}{|c|}{ Soil drenching with neem leaf extract $(1: 5)$} & $30.50 \mathrm{~b}$ & $9.33 \mathrm{fg}$ & $12.93 \mathrm{ef}$ & $245.68 \mathrm{gh}$ & $21.48 \mathrm{gh}$ \\
\hline$"$ & neem oil $(0.5 \%)$ & $25.00 \mathrm{~d}$ & $10.00 \mathrm{de}$ & $14.78 \mathrm{cde}$ & 274.94 ef & $22.39 \mathrm{fg}$ \\
\hline$"$ & garlic extract (1:5) & $8.63 \mathrm{~g}$ & $11.27 \mathrm{~b}$ & $18.89 \mathrm{a}$ & $350.92 \mathrm{a}$ & $29.66 \mathrm{ab}$ \\
\hline$"$ & marsh pepper plant extract $(1: 5)$ & $12.50 \mathrm{f}$ & $10.89 \mathrm{bc}$ & $17.11 \mathrm{ab}$ & $325.10 \mathrm{bc}$ & $27.48 \mathrm{~cd}$ \\
\hline$"$ & allamanda leaf extract $(1: 5)$ & $8.50 \mathrm{~g}$ & $9.44 \mathrm{fg}$ & $17.45 \mathrm{ab}$ & $331.56 \mathrm{~b}$ & $28.33 \mathrm{bc}$ \\
\hline$"$ & wood apple leaf extract $(1: 5)$ & $20.33 \mathrm{e}$ & $10.30 \mathrm{~d}$ & $16.56 \mathrm{bc}$ & 314.64 bcd & $26.85 \mathrm{~cd}$ \\
\hline$"$ & betel leaf extract $(1: 5)$ & $25.00 \mathrm{~d}$ & $9.00 \mathrm{~g}$ & $14.00 \mathrm{def}$ & $266.00 \mathrm{fg}$ & $23.22 \mathrm{fg}$ \\
\hline$"$ & Trichoderma viride broth $(1: 5)$ & $20.53 \mathrm{e}$ & $9.67 \mathrm{ef}$ & $16.55 \mathrm{bc}$ & $314.46 \mathrm{bcd}$ & $27.00 \mathrm{~cd}$ \\
\hline$"$ & T. harzianum broth $(1: 5)$ & $29.16 \mathrm{c}$ & $7.67 \mathrm{~h}$ & $16.11 \mathrm{bcd}$ & $306.10 \mathrm{~cd}$ & $26.95 \mathrm{~cd}$ \\
\hline$"$ & T. viride compost $(1 \mathrm{t} / \mathrm{ha})$ & $20.63 \mathrm{e}$ & $10.45 \mathrm{~cd}$ & $16.00 \mathrm{bcd}$ & $304.00 \mathrm{~cd}$ & $25.81 \mathrm{de}$ \\
\hline$"$ & T. harzianum compost ( $1 \mathrm{t} / \mathrm{ha})$ & $30.81 \mathrm{e}$ & $9.67 \mathrm{ef}$ & $15.89 \mathrm{bcd}$ & $301.92 \mathrm{de}$ & 24.01 ef \\
\hline$"$ & Provax ( $2 \mathrm{~g} / \mathrm{l}$ water) (Positive control) & $7.65 \mathrm{~g}$ & $12.00 \mathrm{a}$ & $19.26 \mathrm{a}$ & $365.94 \mathrm{a}$ & $30.55 \mathrm{a}$ \\
\hline \multicolumn{2}{|c|}{ Untreated soil (negative control) } & $37.50 \mathrm{a}$ & $7.56 \mathrm{~h}$ & $11.90 \mathrm{f}$ & $226.10 \mathrm{~h}$ & $20.19 \mathrm{~h}$ \\
\hline \multicolumn{2}{|c|}{$\operatorname{LSD}(\mathrm{p} \geq 0.05)$} & 0.983 & 0.46 & 2.12 & 23.90 & 1.99 \\
\hline \multicolumn{2}{|c|}{$\mathrm{CV}(\%)$} & 3.99 & 2.14 & 5.83 & 3.26 & 3.39 \\
\hline
\end{tabular}

In a column, similar letter(s) do not differ significantly at $1 \%$ level of probability.

The potential of Trichoderma spp. as biocontrol agent against various plant pathogenic fungi has been well reported by many researchers. In the present investigation, soil drenching with two species of Trichoderma broth showed better yield than Trichoderma compost. Broth is a liquid formulation so it can easily mix with soil particles compared to compost. The inhibitory effect of these bioagents against the tested pathogen was probably due to competition and or antibiosis. Sundaramoorthy and Balabaskar (2013) reported that the application of Trichoderma harzianum (ANR-1) under greenhouse conditions exhibited the least disease incidence (15.33\%). In the present study, the lowest wilt incidence was reported by $T$. viridae broth which was $20.53 \%$. This difference might be due to the different strains of Trichoderma spp.

From the above study, it may be concluded that Allium sativum garlic extract and Allamanda schottii allamanda leaf extract may be incorporated in biofungicides formulation which may be used in integrated management approach in controlling Fusarium wilt and increasing yield of tomato under field condition.

\section{Acknowledgements}

The authors are grateful to the Chairman of the Department of Botany, Rajshahi University and Regional Agricultural Research Station, BARI, Ishurdi, Pabna, Bangladesh for providing the necessary facilities. The authors are also thankful to the Ministry of Science and Technology, Government of the People's Republic of Bangladesh for financial support. 


\section{References}

Agbenin ON and Marley PS 2006. In vitro assay of some plant extracts against Fusarium oxysporum f. sp. lycopersici causal agent of tomato wilt. J. Plant Prot. Res. 46: 215-220.

Ahmed M 2011. Management of Fusarium wilt of tomato by soil amendment with Trichoderma koningii and a white sterile fungus. Indian J. Res. 5: 35-38.

Asha BB, Chandra NS, Udaya SAC, Srinivas C and Niranjana SR 2011. Biological control of Fusarium oxysporum f. sp. lycopersici causing wilt of tomato with Pseudomonas fluorescents. Int. J. Microbiol. Res. 3: 79-84.

Boulenouar N, Marouf A and Cheriti A 2009. Effect of some poisonous plants extracts on Fusarium oxysporum f. sp. albedinis. J. Biol. Sci. 9: 594-600.

Bowers JH and Locke JC 2000. Effect of botanical extracts on population density of Fusarium oxysporum in the soil and control of Fusarium wilt in the green house. Plant Dis. 84: 300-305.

Cal A, Larena I, Sabuquillo P and Melgarejo P 2004. Biological control of tomato wilts. Recent Res. Dev. Crop Sci. 1: 97-115.

El-Rafai IM, Asswah SMW and Awdalla OA 2003. Biocontrol of some tomato diseases using some antagonistic microorganisms. Pakistan J. Biol. Sci. 6: 399-406.

Gomez KA and Gomez AA 1984. Statistical Procedures for Agricultural Research (2nd ed), Willy and Sons, New York, pp. 187-240.

Hassanein NM, Abou Zeid MA, Youssef KA and Mahmoud DA 2010. Control of tomato early blight and wilt using aqueous extract of neem leaves. Phytopathol. Mediterr. 49: 143-151.

Hend A and Perveen K 2012. Biological control of Fusarium wilt of tomato by antagonist fungi and cyanobacteria. African J. Biotechnol. 11: 1100-1105.

Islam MT and Faruq AN 2012. Effect of some medicinal plant extracts on damping-off disease of winter vegetable. World Appl. Sci. J. 17 (11): 1498-1503.

Islam MA, Aminuzzaman FM, Islam MR and Zamal MS 2006. Seed treatment with plant extract and Vitavax-200 in controlling leaf spot (Bipolaris sorokiniana) with increasing grain yield of wheat. Inter. J. Sust. Agri. Technol. 2(8): 15-20.

Jaiswal K, Tiwari S, Faisal M and Shukla HO 2015. Biological control of tomato wilt through soil application of bio-agent and organic amendments. J. Eco-friendly Agri. 10(2): 189-190.

Khayungarnnawee A, Phatvet W, Sematong T, Thubthimthed S and Suntorntanasat T 2004. P12 Preminary study on sedative effect of Guava (Psidium guajava L.) leaf oil. Thai J. Pharmacol. 29: 76-77.

Neela FA, Sonia IA and Shamsi S 2014. Antifungal activity of selected medicinal plant extract on Fusarium oxysporum Schlechtthe causal agent of fusarium wilt disease in tomato. American J. Plant Sci. 5(18): 2665-2671.

Okwu DE 2004. Phytochemical and vitamin contents of indigenous spices of South Eastern Nigeria. J. Sust. Agri. Environ. 6: 30-37.

Pattanaik S, Subramanyam VR and Kole C 2002. Antibacterial and antifungal activity of the essential oils in vitro. Microbiosis 86: 237-246.

Pizana CG, Necha LLB and Gomez MYR 2010. Evaluation of the fungicidal activity of leaves powders and extracts of fifteen mexican plants against Fusarium oxysporum f. sp. gladioli (massey) Snyder and Hansen, Plant Pathol. J. 9: 103-111.

Ramezani H 2008. Biological control of root-rot of eggplant caused by Macrophomina phaseolina. American Eurasian J. Agri. Environ. Sci. 4: 218-220.

Siddaramaiah AL, Krishnaprasad KS and Hegde RK 1978. Epidemiological studies of mulberry leaf spot caused by Cercospora moricula Cook. Indian J. Sericul. 16: 44-47.

Sundaramoorthy S and Balabaskar P 2013. Biocontrol efficacy of Trichoderma spp. against wilt of tomato caused by Fusarium oxysporum f. sp. lycopersici. J. Appl. Biol. Biotechnol. 1: 36-40.

(Manuscript received on 13 January, 2019; revised on 3 May, 2019) 